\title{
Composition, structure and diversity of a mesquite in Pesquería (Northeastern Mexico)
}

\author{
Eduardo Alanís-Rodríguez', Víctor M. Molina-Guerra², Javier Jiménez-Pérez ${ }^{1}$, Ernesto A. Rubio-Camacho³, \\ Arturo Mora-Olivo $^{4^{*}}$ (D) Alejandro Collantes-Chávez-Costa ${ }^{5}$ and Jonathan J. Marroquín-Castillo ${ }^{1}$
}

\begin{abstract}
Background: Although the mesquite (mesquital or mezquital in Spanish) is one of the representative ecosystems of the landscapes in the north of Mexico, it is also one of the least studied. This study evaluated the structure (horizontal and vertical) and diversity of a plant community of mesquite in Northeastern Mexico. Three plots of $1,600 \mathrm{~m}^{2}$ each were established. All trees and shrubs with a basal diameter $\left(\mathrm{d}_{0.10}\right) \geq 0.5 \mathrm{~cm}$ were recorded, and total height $(h)$ and crown diameter $\left(\mathrm{d}_{\text {crown }}\right)$ were measured.

Results: There were 8 families, 12 genera and 14 species. The genus presenting the most species was Acacia (three species). The most representative family was Fabaceae with seven species. The evaluated community presents a density of $375 \mathrm{~N} / \mathrm{ha}$ and a crown area of $6,600 \mathrm{~m}^{2} / \mathrm{ha}$. The species with the highest values on the Importance Value Index (IVI) were Prosopis glandulosa (15.95\%), Acacia amentacea (14.50\%), Havardia pallens (14.27\%) and Acacia farnesiana (11.22\%). These four species account for $55.94 \%$ of IVI. The value obtained from the Vertical Species Profile Index (A) was 3.03, with an $A_{\max }$ of 3.74 and an $A_{\text {rel }}$ of $81.15 \%$, indicating high structural diversity in the high strata. The evaluated plant community had a Margalef Diversity Index value of $D_{M g}=2.50$ and a Shannon Index value of $H^{\prime}=2.28$, values which are intermediate and considered to be common in the scrublands of Northeastern Mexico.

Conclusions: 1) The studied community presents intermediate values that are considered as common in comparison to other arid and semi-arid vegetation associations of Northeastern Mexico. 2) The abundance curve of the species was well adjusted to the geometric model, and the distribution is associated with adverse environments such as semi-arid. 3) The family with greater importance for its contribution to the community is Fabaceae, while the genus with more species was Acacia. The research generated quantitative information of the plant community of a mesquite which is in a phase of mature ecological succession.
\end{abstract}

Keywords: Importance value index, Margalef diversity index, Mesquital, Plant community, Prosopis glandulosa, Shannon index

\section{Background}

Mesquites are spiny trees or shrubs of the pea family that grow preferentially on flat deep soils in arid and semi-arid zones of Asia, Africa and mainly America [1-4]. These vegetal communities have been called different names such as mesquite forest, mesquite

\footnotetext{
* Correspondence: amorao@uat.edu.mx

${ }^{4}$ Instituto de Ecología Aplicada, Universidad Autónoma de Tamaulipas,

División del Golfo 356, 87019 Ciudad Victoria, Tamaulipas, México

Full list of author information is available at the end of the article
}

woodland, thorny forest, thorny deciduous forest, high thorny scrub or low thorny evergreen forest [4-7]. However, what predominantly characterizes mesquites is the dominance of a species of the genus Prosopis in their upper strata [8].

The distribution of mesquites within the New World and particularly Mexico is irregular due to the environmental and geographical conditions wherever they are present. In some cases, they occupy reduced and isolated areas when associated with other types of vegetation 
such as saltbush, thorny scrub, tropical forest, or submontane scrub [9]. Furthermore, it is also located in extensive and continuous areas such as the Coastal Plains of Mexico [4].

In the Northeastern Mexico, mesquites have been described in Tamaulipas [10], Coahuila [8], and Nuevo León [11-13]. Such communities with Prosopis glandulosa Torr., P. laevigata (Humb. \& Bonpl. ex Willd.) M.C. Johnst. or $P$. tamaulipana Burkart have been studied because of their importance from the ecological point of view and the potential use for their flora. Unfortunately, it is common for such work to note the advanced state of deterioration of mesquites that is attributed to changes in and use for agriculture and livestock, to the exploitation of Prosopis spp. as raw material for timber, fuel, fodder and other uses [2].

For the case of Nuevo Leon, the descriptions of the mesquites are more related to floristic attributes or forestry point of view, which are the reasons data on community structure are scarce. Although Briones and Villarreal [11] describe a thorny thicket of Prosopis-Acacia in the north of the state, this does not include ecological data that describe the structure of this plant community in detail. In this context, and considering the need of studies that describe in detail the current state and the structure of the mesquites that still persist in the Northeastern Mexico, this work was carried out. The objective of this study was to know the structure (horizontal and vertical) and floristic diversity of a mesquite community located in Northeastern Mexico, and particularly in the center of the state of Nuevo Leon.

\section{Methods}

Area of study

The present research was carried out in the conservation area of the Ternium Industrial Center of México, which has an area of 46 hectares and is located within the municipality of Pesquería, Nuevo León, in Northeastern Mexico (Fig. 1). It is located between latitude $25^{\circ} 45^{\prime} \mathrm{N}$ and longitude $99^{\circ} 58^{\prime} \mathrm{W}$, at an average altitude of 306 masl, which belongs to the physiographic region of the North Gulf Coastal Plain [6]. The predominant climate is very dry and semi-warm (Bwhw), with an average annual temperature in the range from 20 to $21{ }^{\circ} \mathrm{C}$. The types of soils present in the majority of cases are xerosol, castañozem, feozem, regosol and in the minority of cases are fluvisol, vertisol and rendzine. The average annual rainfall is $550 \mathrm{~mm}$. The vegetation of the area corresponds to a mesquital with a history of cattle and hunting use and is currently disturbed [14].

\section{Analysis of the vegetation}

In order to fulfill the objective, the "c" sub basin of the Pesquería River with in a low part of the San Juan River Basin (Rio Bravo, Rio Bravo) was selected, where the conservation area is located and where intermittent surface runoff occurs. Vegetation evaluation was carried out using three randomly distributed sampling sites. The dimensions of each site was $40 \mathrm{~m} \times 40 \mathrm{~m}\left(1,600 \mathrm{~m}^{2}\right)$. A census was taken of all shrub and tree species with a basal diameter $\left(\mathrm{d}_{0.10}\right) \geq 5 \mathrm{~cm}$. The species of each individual was identified and recorded, taking the measurements of total height $(\mathrm{h})$ and crown diameter $\left(\mathrm{d}_{\text {crown }}\right)$ in north-south and east-west directions. For the nomenclature of families,

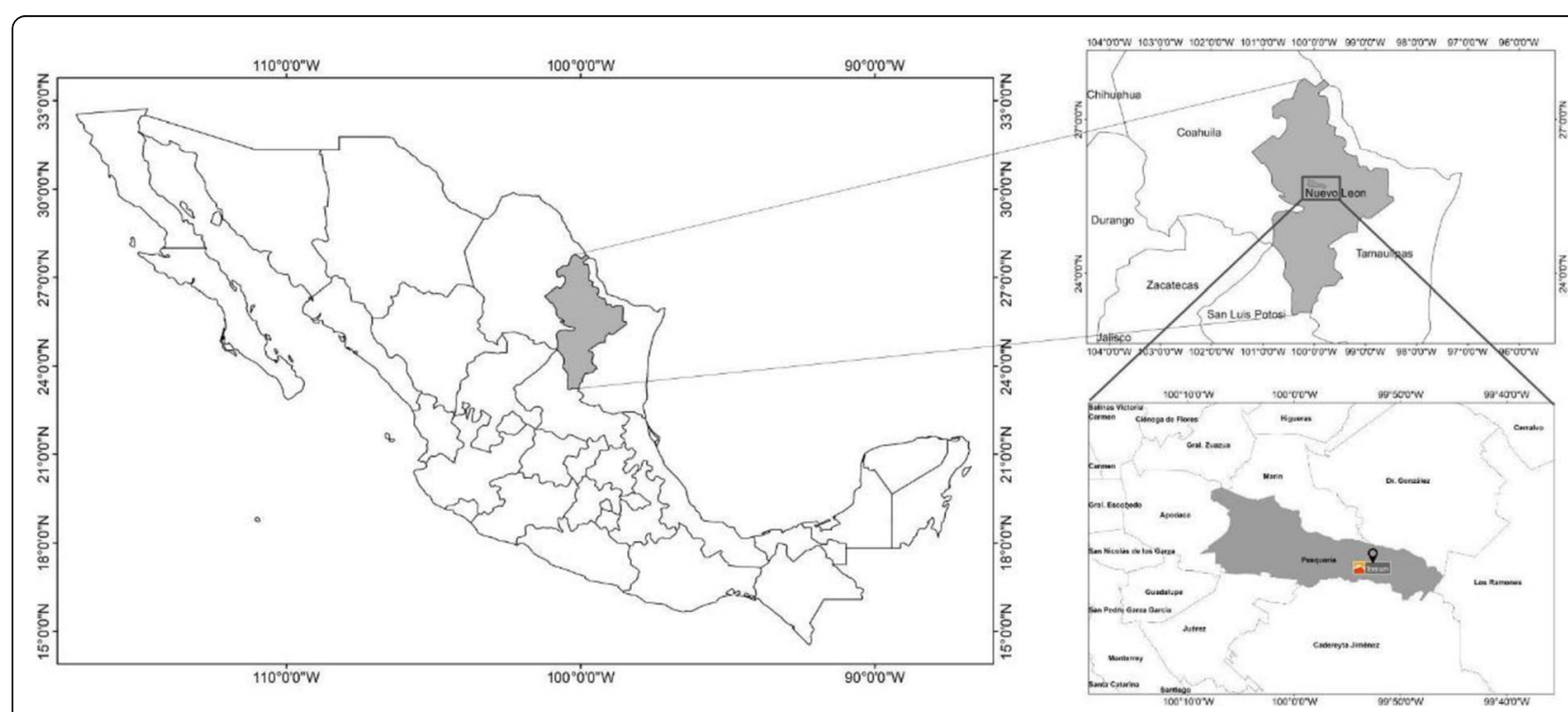

Fig. 1 Location of the study area. On the left side, the Mexican Republic is indicated, on the upper right side the superior right the State of Nuevo Leon is indicated, and on the lower right side the Municipality of Pesquería is indicated 
orders and species we followed the APG III [15], and the scientific names and families were corroborated in the database of Tropicos [16].

\section{Data analysis}

\section{Structure}

In order to evaluate the horizontal structure of the species in the study community, we used the following structural variables: abundance, dominance, frequency, with which we calculated the Importance Value Index (IVI) which was calculated from the following mathematical equations $[17,18]$ :

$$
\begin{aligned}
& A_{i}=N i / S \\
& A R_{i}=\left(\frac{A_{i}}{\sum A_{i}}\right) * 100 \\
& i=1 \ldots n
\end{aligned}
$$

Where $A R_{i}$ is the relative abundance of species $i$, with respect to total abundance $\left(A_{i}\right) ; N i$ is the number of individuals of species $i$, and $S$ is the surface (ha).

To estimate the relative dominance we used:

$$
\begin{aligned}
& D_{i}={ }^{A b_{i}} / S(h a) \\
& D R_{i}=\left({ }^{D_{i}} / \sum D_{i}\right) * 100 \\
& i=1 \ldots n
\end{aligned}
$$

Where $D R_{i}$ is the relative dominance of species $i$, with respect to total dominance $\left(D_{i}\right) ; A b_{i}$ is the crown area of species $i$, and $S$ is the surface (ha).

$$
\begin{aligned}
& F_{i}=P_{i} /_{N S} \\
& F R_{i}=\left(F_{i} / \sum F_{i}\right) * 100 \\
& i=1 \ldots n
\end{aligned}
$$

Where $F R_{i}$ is the relative frequency of species $i$ with respect to the total frequency $\left(F_{i}\right) ; P_{i}$ is the frequency of species $i$ at sampling sites, and $N S$ is the total number of sampling sites. The Importance Value Index (IVI) is defined as:

$$
I V I=\frac{\sum_{n}^{i=1}\left(A R_{i}, D R_{i}, F R_{i}\right)}{3}
$$

where $A R_{i}$ is the relative abundance; $D R_{i}$ is the relative dominance, and $F R_{i}$ is the relative frequency.

A graph of height classes was generated in order to evaluate the vertical structure of the community. The Vertical
Distribution Index of Pretzsch [19] was calculated for three zones of height: zone I: $80-100 \%$ of the maximum height of the population, zone II: $50-80 \%$ of the maximum height of the population, zone III: $0-50 \%$ of the maximum height of the population [19]. In this study was the high strata $(7.20-9.00 \mathrm{~m})$, medium strata $(4.50-7.19 \mathrm{~m})$ and low strata $(<4.50 \mathrm{~m})$. The Vertical Distribution Index was calculated according to the following mathematical formula:

$$
A=-\sum_{i=1}^{S} \sum_{j=1}^{Z} p_{i j} * \ln \left(p_{i j}\right)
$$

Where $S$ is the number of species present; $Z$ is the number of height zones and pij is the proportion of species in each height zone:

$$
p i j=n i j / N
$$

where $n i j$ is the number of individuals of the same species $(i)$ in the zone $(j)$ and $N$ is total number of individuals.

In order to compare the Pretzsch Index it is necessary to standardize it and this is undertaken by the value of $A_{\max }$, which is calculated in the following manner:

$$
\operatorname{Amax}=\operatorname{In}(S * Z)
$$

Then the value of $A$ can be standardized according to:

$$
\text { Arel }=\frac{A}{\operatorname{In}(S * Z)} * 100
$$

\section{Diversity}

To estimate species diversity, the Shannon Index [20] and the Margalef index [21], respectively, were estimated. The Shannon Index was estimated by using the following equation:

$$
H^{\prime}=-\sum_{i=1}^{S} p_{i} * \ln \left(p_{i}\right)
$$

where $S$ is the number of species present, $\ln$ is natural logarithm and $p i$ is the proportion of species. $P_{i}=n_{i} / N$, where $n_{i}$ is the number of individuals of species $i$ and $N$ is the total number of individuals. With the same meaning of the variables being common, the Margalef Diversity Index $\left(D_{a}\right)$ was estimated using the following equation:

$$
D a=\frac{(S-1)}{\log N}
$$

\section{Species abundance curves}

Species density was analyzed using species abundance curves. With these curves it is possible to make inferences about the state of the ecosystems, besides using for descriptions in the form of mathematical models. 
In this study, the species abundance curves were fitted to known mathematical models. Currently, there are many models that are used to describe species diversity in a community. However, in this work only three of the best fit models are analyzed: the geometric model [22], the Poisson model of the logarithmic normal series [23], and the Neutral Model of Alonso and Mckane [24, 25].

For the selection of the best model, the Akaike Information Criterion (AIC) was used to compare the selected models, taking into account their fit and complexity. When comparing models using this method, the selection of the best model is based on the lowest value in the AIC. In addition, we used the delta AIC criterion (dAIC) which, when it has a value that is less than 2 , indicates that the comparative models similarly explain the trend of the data, (that is, there are no differences between one and the other). To determine the goodness of fit of the models $\chi^{2}$ was used, as recommended by Magurran [26].

\section{Adjusting the models}

The models were adjusted using the maximum likelihood method with software $R$ version 3.1.2 [17], with the support of RStudio version 0.99 [27] and also running routines by Prado et al. [25].

\section{Results}

\section{Composition}

The presence of 8 families, 12 genera and 14 species was recorded. The genus with more species present in the study area was Acacia with three species. The most representative family was Fabaceae with seven species, and the rest presented one species each (Table 1). According to the biological form, nine species are shrubs and five species are trees.

\section{Community structure}

The abundance of the evaluated plant species was 375 $\mathrm{N} /$ ha. The most abundant species within the community were Acacia amentacea with $85 \mathrm{~N} / \mathrm{ha}$, Havardia pallens with 73 N/ha, and Prosopis glandulosa with 42 N/ha. When added these three species equal $200 \mathrm{~N} / \mathrm{ha}$, representing $53.33 \%$ of the total abundance of the evaluated plant community.

The evaluated community crown area was $6,600 \mathrm{~m}^{2} / \mathrm{ha}$, representing $66.00 \%$ coverage. The species that presented the greatest dominance were Prosopis glandulosa with 26.30\%, Acacia farnesiana with $17.42 \%$, and Havardia pallens with $13.00 \%$, amounting to $56.72 \%$ of the total coverage. The most frequent species had some presence in the three evaluated sites, and were Acacia amentacea, Cordia boissieri, Havardia pallens, Prosopis glandulosa, and Sideroxylon celastrinum.

\section{Importance value}

The species with the highest Importance Index were Prosopis glandulosa (15.95\%), Acacia amentacea (14.50\%), Havardia pallens (14.27\%), and Acacia farnesiana (11.22\%; Table 2). These four species account for $55.94 \%$ of IVI.

\section{Vertical structure}

The total height of the evaluated individuals fluctuated between $2.3 \mathrm{~m}$ and $9.00 \mathrm{~m}$. The highest abundance of individuals is represented in the height class 5-7 $\mathrm{m}$ with $173 \mathrm{~N} / \mathrm{ha}$ which is equivalent to $46 \%$ of the evaluated population, followed by class 3-5 m with $118 \mathrm{~N} /$ ha representing $31 \%$ of the evaluated population (Fig. 2).

According to the classification proposed by Pretzsch, where three high strata are established, the high stratum is composed of $60 \mathrm{~N} / \mathrm{ha}$ (16.11\% of the population) belonging

Table 1 Scientific name, common name, family and biological form of the registered species

\begin{tabular}{|c|c|c|c|}
\hline Scientific Name & Common Name & Family & Biological Form \\
\hline Acacia amentacea DC. & Gavia & Fabaceae & Shrub \\
\hline Acacia farnesiana (L.) Willd. & Huizache & Fabaceae & Shrub \\
\hline Acacia schaffneri (S. Watson) F.J. Herm. & Huizache chino & Fabaceae & Shrub \\
\hline Celtis pallida Torr. & Granjeno & Cannabaceae & Shrub \\
\hline Cordia boissieri A. DC. & Anacahuita & Boraginaceae & Shrub \\
\hline Diospyros palmeri Eastw. & Chapote blanco & Ebenaceae & Tree \\
\hline Ebenopsis ebano (Berland.) Barneby \& J.W. Grimes & Ébano & Fabaceae & Tree \\
\hline Forestiera angustifolia Torr. & Panalero & Oleaceae & Shrub \\
\hline Guaiacum angustifolium Engelm. & Guayacán & Zygophyllaceae & Shrub \\
\hline Havardia pallens (Benth.) Britton \& Rose & Tenaza & Fabaceae & Shrub \\
\hline Parkinsonia texana (A. Gray) S. Watson & Palo verde & Fabaceae & Tree \\
\hline Prosopis glandulosa Torr. & Mezquite & Fabaceae & Tree \\
\hline Sideroxylon celastrinum (Kunth) T.D. Penn. & Coma & Sapotaceae & Tree \\
\hline Zanthoxylum fagara (L.) Sarg. & Colima & Rutaceae & Shrub \\
\hline
\end{tabular}


Table 2 Abundance, dominance, frequency, and Importance Value Index (IVI) of the species recorded (ranked according to their IVI value)

\begin{tabular}{|c|c|c|c|c|c|c|c|}
\hline \multirow[t]{3}{*}{ Species } & \multirow{2}{*}{\multicolumn{2}{|c|}{ Abundance }} & \multirow{2}{*}{\multicolumn{2}{|c|}{$\begin{array}{l}\text { Dominance } \\
\text { (crown area) }\end{array}$}} & \multirow{2}{*}{\multicolumn{2}{|c|}{ Frecuency }} & \multirow[t]{3}{*}{$\mid \mathrm{VI}$} \\
\hline & & & & & & & \\
\hline & N/ha & $\%$ & $\mathrm{~m}^{2} / \mathrm{ha}$ & $\%$ & N/Site & $\%$ & \\
\hline Prosopis glandulosa & 42 & 11.20 & 1,736 & 26.30 & 100 & 10.34 & 15.95 \\
\hline Acacia amentacea & 85 & 22.67 & 693 & 10.50 & 100 & 10.34 & 14.50 \\
\hline Havardia pallens & 73 & 19.47 & 858 & 13.00 & 100 & 10.34 & 14.27 \\
\hline Acacia farnesiana & 35 & 9.33 & 1,150 & 17.42 & 66.67 & 6.90 & 11.22 \\
\hline Parkinsonia texana & 27 & 7.20 & 656 & 9.94 & 33.33 & 3.45 & 6.86 \\
\hline Celtis pallida & 17 & 4.53 & 508 & 7.69 & 66.67 & 6.90 & 6.37 \\
\hline Diospyros palmeri & 21 & 5.60 & 177 & 2.68 & 66.67 & 6.90 & 5.06 \\
\hline Cordia boissieri & 13 & 3.47 & 84 & 1.27 & 100 & 10.34 & 5.03 \\
\hline Sideroxylon celastrinum & 10 & 2.67 & 110 & 1.67 & 100 & 10.34 & 4.89 \\
\hline Zanthoxylum fagara & 21 & 5.60 & 260 & 3.94 & 33.33 & 3.45 & 4.33 \\
\hline Acacia schaffneri & 19 & 5.07 & 157 & 2.38 & 33.33 & 3.45 & 3.63 \\
\hline Forestiera angustifolia & 6 & 1.60 & 105 & 1.59 & 66.67 & 6.90 & 3.36 \\
\hline Guaiacum angustifolium & 4 & 1.07 & 47 & 0.71 & 66.67 & 6.90 & 2.89 \\
\hline Ebenopsis ebano & 2 & 0.53 & 60 & 0.91 & 33.33 & 3.45 & 1.63 \\
\hline Sum & 375 & 100 & 6,601 & 100 & & 100 & 100 \\
\hline
\end{tabular}

to five species, the mean stratum by $221 \mathrm{~N} / \mathrm{ha}(58.89 \%$ of the population) of 12 species, and the low stratum by $94 \mathrm{~N} / \mathrm{ha}(25 \%$ of the population) with 13 species.

The species found in the three strata of height are Acacia amentacea, Acacia farnesiana, Havardia pallens, Parkinsonia texana, and Prosopis glandulosa. Those species that are well represented in the vertical structure of the community are also those that presented the highest IVI values in the horizontal structure.

The value obtained from the Vertical Species Profile Index (A) was 3.03, with an $A_{\max }$ of 3.74, and an $A_{\text {rel }}$ of $81.15 \%$, indicating high vertical structural diversity. The values of $A_{\text {rel }}$ are close to $100 \%$ indicating that species and abundances are evenly distributed in the three height strata (Table 3).

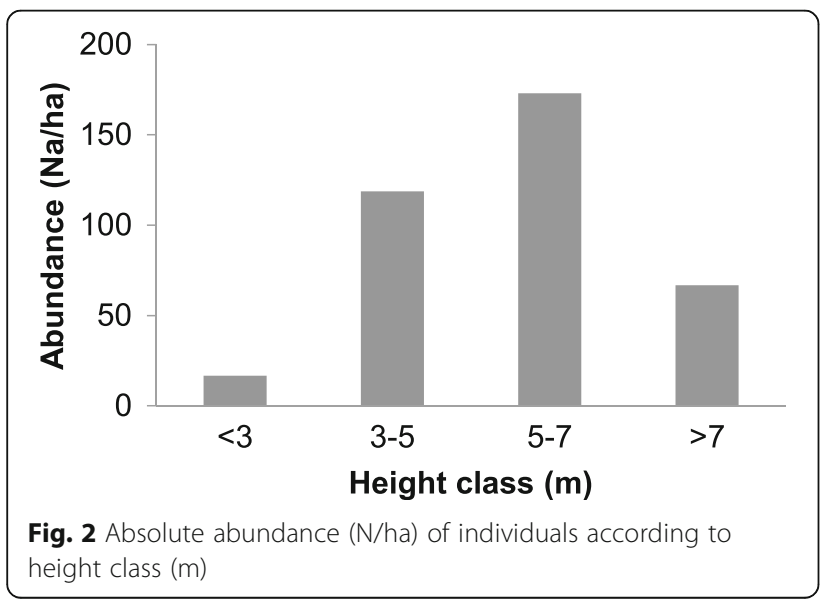

Species diversity

The evaluated plant community had a Margalef Diversity Index value of $D_{M g}=2.50$ and a Shannon Index value of $H^{\prime}=2.28$.

\section{Species rank abundance curves}

The known models were fitted and the best was a geometric model (Fig. 3), followed by the Poisson LogNormal model $\left(\mathrm{AIC}=123.86, \mathrm{dAIC}=2.34, x^{2}=7.5581, \mathrm{df}=13\right.$, $p=0.87$ ), which is followed by the Neutral model (AIC = 131.25, dAIC $\left.=9.72, x^{2}=184.89 ; \mathrm{df}=13, p<0.001\right)$.

\section{Discussion}

\section{Composition}

The composition observed in our study resembles that reported by Briones and Villarreal [11], in the thorny bush of Prosopis-Acacia. According to these authors, the composition and physiognomy correspond to the extra-desert mesquite described by Rezedowski [4] for the state of San Luis Potosí, and the spiny and evergreen forest [7]. However, the composition differs from other studies in which Prosopis sp. (mesquite) dominates the arboreal strata in a mono-specific manner [8]. There are associations similar to those reported in our study, but with lower heights, which are described by Briones and Villarreal [11], such as the medium thorny scrub of Prosopis-Acacia.

The most representative family of the mesquite was Fabaceae, and the others families only presented one species. This record is similar to that obtained by Montaño et al. [28], who report the same number of families in spite of having a greater number of species, 
Table 3 Absolute Abundance (N/ha) and proportional abundance (of the total, and in the zone) with respect to height strata of the registered species. High strata $(7.20-9.00 \mathrm{~m})$, medium strata $(4.50-7.19 \mathrm{~m})$ and low strata $(<4.50 \mathrm{~m})$

\begin{tabular}{|c|c|c|c|c|}
\hline & & & Proportion \% & \\
\hline Strata I & $\mathrm{N}$ & $\mathrm{N} / \mathrm{ha}^{-1}$ & Of the total & In the zone \\
\hline Acacia amentacea & 9 & 19 & 5 & 31.03 \\
\hline Acacia farnesiana & 5 & 10 & 2.78 & 17.24 \\
\hline Havardia pallens & 7 & 15 & 3.89 & 24.14 \\
\hline Parkinsonia texana & 2 & 4 & 1.11 & 6.9 \\
\hline Prosopis glandulosa & 6 & 13 & 3.33 & 20.69 \\
\hline Sum & 29 & 61 & 16.11 & 100 \\
\hline Strata II & $\mathrm{N}$ & N/ha & Of the total & In the zone \\
\hline Acacia amentacea & 29 & 60 & 16.11 & 27.36 \\
\hline Acacia farnesiana & 10 & 21 & 5.56 & 9.43 \\
\hline Acacia schaffneri & 3 & 6 & 1.67 & 2.83 \\
\hline Celtis pallida & 6 & 13 & 3.33 & 5.66 \\
\hline Cordia boissieri & 1 & 2 & 0.56 & 0.94 \\
\hline Diospyros palmeri & 5 & 10 & 2.78 & 4.72 \\
\hline Ebenopsis ebano & 1 & 2 & 0.56 & 0.94 \\
\hline Havardia pallens & 26 & 54 & 14.44 & 24.53 \\
\hline Parkinsonia texana & 8 & 17 & 4.44 & 7.55 \\
\hline Prosopis glandulosa & 9 & 19 & 5 & 8.49 \\
\hline Sideroxylon celastrinum & 2 & 4 & 1.11 & 1.89 \\
\hline Zanthoxylum fagara & 6 & 13 & 3.33 & 5.66 \\
\hline Sum & 106 & 221 & 58.89 & 100 \\
\hline Strata III & $\mathrm{N}$ & N/ha & Of the total & In the zone \\
\hline Acacia amentacea & 3 & 6 & 1.67 & 6.67 \\
\hline Acacia farnesiana & 2 & 4 & 1.11 & 4.44 \\
\hline Acacia schaffneri & 6 & 13 & 3.33 & 13.33 \\
\hline Celtis pallida & 2 & 4 & 1.11 & 4.44 \\
\hline Cordia boissieri & 5 & 10 & 2.78 & 11.11 \\
\hline Diospyros palmeri & 5 & 10 & 2.78 & 11.11 \\
\hline Forestiera angustifolia & 3 & 6 & 1.67 & 6.67 \\
\hline Guaiacum angustifolium & 2 & 4 & 1.11 & 4.44 \\
\hline Havardia pallens & 2 & 4 & 1.11 & 4.44 \\
\hline Parkinsonia texana & 3 & 6 & 1.67 & 6.67 \\
\hline Prosopis glandulosa & 5 & 10 & 2.78 & 11.11 \\
\hline Sideroxylon celastrinum & 3 & 6 & 1.67 & 6.67 \\
\hline Zanthoxylum fagara & 4 & 8 & 2.22 & 8.89 \\
\hline Sum & 45 & 91 & 25 & 100 \\
\hline Total sum & 180 & 375 & 100 & 300 \\
\hline
\end{tabular}

also with the most representative being the Fabaceae, a characteristic situation for the xerophilous scrub of this region. The most representative species (Prosopis

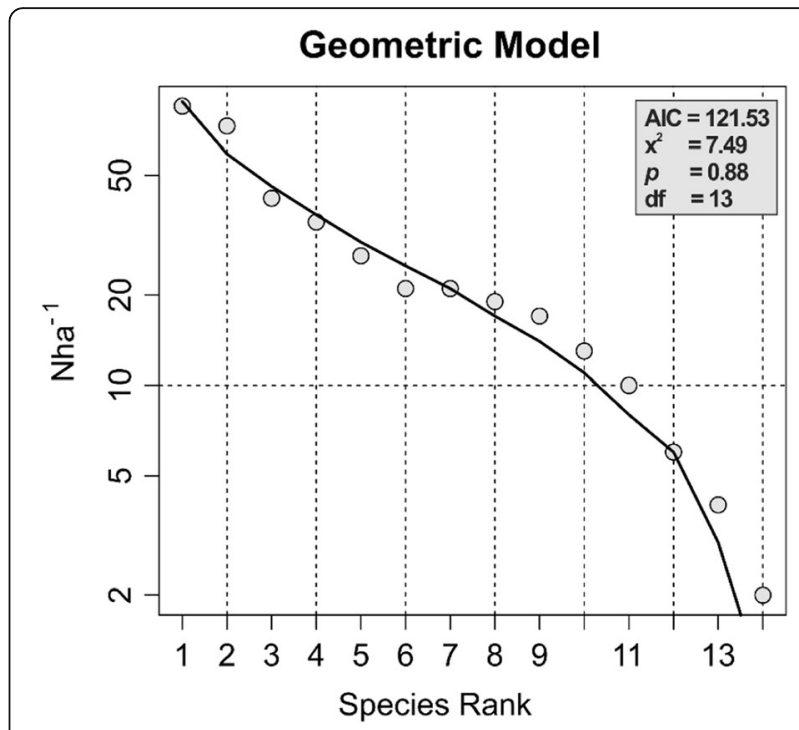

Fig. 3 Range of species abundance in the study area, where: N/ha = Number of trees per hectare, AIC = Akaike's Information Criterion, $x^{2}=$ Chi-square test, $d f=$ degree of freedom test $X^{2}, p=$ probability value of the test $x^{2}$

glandulosa, Acacia amentacea, Havardia pallens, and Acacia farnesiana) in this study are reported as being characteristic of this type of community [29]. The mesquite woodland includes forests dominated by Prosopis glandulosa var. torreyana and var. glandulosa, which are recorded in areas that have been disturbed [30], and these are frequently associated with species such as Forestiera angustifolia, Leucophyllum frutescens, Ziziphus obtusifolia, Acacia rigidula ( $=A$. amentacea), A. berlandieri, Celtis pallida, and Karwinskia humboldtiana [13], the same species as recorded in the present investigation.

\section{Structure}

The three species with high abundance were Acacia amentacea, Havardia pallens, and Prosopis glandulosa, and these results are in agreeance with those of Estrada et al. [29], who notes that these species are the most abundant. Montaño et al. [28] note that in Mexico's xerophilous scrub, mesquite is an abundant species and possibly a key species in disturbed scrubland. RojasMendoza [13], INEGI [6] and Estrada et al. [29] note that it is a species that resists the effects of disturbance and is thus associated with disturbed zones.

The evaluated community has a coverage of $66 \%$ $\left(6,600 \mathrm{~m}^{2} / \mathrm{ha}\right)$, which means that $34 \%$ of the area is devoid of vegetation. This may be due to the fact that only individuals greater than $5 \mathrm{~cm}$ in diameter were considered, since for similar communities in Northeastern Mexico that considered smaller individuals, coverage greater than $100 \%\left(13,973 \mathrm{~m}^{2} / \mathrm{ha}\right)$ was recorded, which denotes a considerable overlap of crowns [31]. 
The most frequent species are the genus Prosopis and Acacia, similar to those reported by Montaño et al. [28], being of greater presence in the mesquites. Similarly, Mora-Donjuan et al. [32], note that the genus Prosopis has a greater frequency in the microphyllous desert scrublands.

\section{Vertical structure}

The total height of the evaluated individuals fluctuated between $2.3 \mathrm{~m}$ and $9.00 \mathrm{~m}$. This height is considered high compared to other plant communities of the xerophilous scrub [32]. The value obtained from the Vertical Species Profile Index (A) was 3.03, with an $A_{\max }$ of 3.74 and an $A_{\text {rel }}$ of $81.15 \%$, indicating high vertical structural diversity. Pretzsch [33] notes out that high vertical and horizontal heterogeneity are strongly related to high diversity and ecological stability. This suggests that the species and their abundances are evenly distributed in the three height strata, and that the system is in a good state of conservation. These results are better than those presented by Alanís-Rodríguez et al. [34], Jiménez-Pérez et al. [35], Villavicencio et al. [36], and Mora-Donjuan et al. [32] who determined that the evaluated xerophilous scrub communities, many of which were previously subjected to some type and intensity of use, present only one or two highly dominant strata.

The presence of Acacia amentacea and Parkinsonia texana in the three strata shows the level of adaptation required for these environments. These species are well adapted to water stress, and they use mechanisms to avoid dehydration of their tissues, and to adjust their morpho-physiological characteristics to cope with the long season of dryness, as well as the fixation of active nitrogen [30], which also explains the possibility of their behaving as colonizing species.

\section{Species diversity}

The specific richness that was recorded differs from that documented by Montaño et al. [28], in a larger sampling area which registered 36 species, 14 of which were documented in the present study. This situation is presented by the environmental factors in each research area, Montaño et al. [28] studied a semi-arid spiny scrubland of the Mezquital Valley, where precipitation of $520 \mathrm{~mm}$ and temperature range of $16-24{ }^{\circ} \mathrm{C}$ were similar to the present study precipitation $550 \mathrm{~mm}$ and temperature range of $20-21{ }^{\circ} \mathrm{C}$. The altitude factor positively influences the development of the species, whereby Montaño et al. [28] recorded an altitude of 2013 m.a.s.l compared to the altitude of 306 m.a.s.l in our study. This suggests that environmental factors play a positive role in the species diversity of the study area, although most of the recorded species are distributed exclusively or preferably in the arid or semi-arid zones of Mexico [37, 4].

The low number of species is associated with that the mesquites harboring the lowest number of taxa for the northern zone of the state [29], being that this community has the smaller registered presence of Caesalpiniaceae and Fabaceae. This is largely limited to edaphic features, and mesquites are distributed in the northwestern end of the state, where sandy soils dominate [29].

Regarding the diversity of the community described in the present study, the data presented in other studies do not account for the properties of the studied communities, and therefore, the comparison with other mesquite communities is not feasible. However, the evaluated area showed values of $D_{M g}=2.50$ and $H^{\prime}=$ 2.28 , and these values are similar to those recorded for other xerophilic scrubs. Mora-Donjuan et al. [31] evaluated a reference area of Tamaulipan thorn scrub (TTS) and recorded $D_{M g}=2.26$ and Diversity $H=1.94$. They are also similar to those recorded by Jiménez-Pérez et al. [38], who evaluated the diversity of a regenerated TTS community with agricultural history in Northeastern Mexico and obtained values of $D_{M g}=2.17$ and alpha diversity $H^{\prime}=>2.27$. The values recorded in this study are greater than those of Pequeño-Ledezma et al. [39], who registered values of $D_{M g}=1.40$ and alpha diversity of $H=1.27$ in a post-livestock regeneration area in the Tamaulipan thorn scrub.

As reported in the existing mesquite studies, these communities are mostly reported as monospecific to Prosopis sp., or floristically not very diverse but mainly dominated by Prosopis and Acacia. This qualitative observation, as reported in other studies (e.g. $[11,8]$ ), is consistent with the quantitative results obtained in our study, where high values for Prosopis glandulosa, Acacia amentacea, Havardia pallens, and Acacia farnesiana the species that distinguish the association. The dominance of these taxa over others is also observed in the species abundance curve of the studied community which was adjusted to the geometric model.

\section{Species abundance curves}

In the present study, the fit to the geometric model suggests a typical structure of strongly stressful environments. Magurran [26] describes the species abundance model adjusted to the geometric model as the model associated with adverse environments or initial successive stages, where the limiting conditions prevail. In the case of mesquite, the environment corresponds to that of arid zone [4]. The dominant species (Prosopis glandulosa, Acacia amentacea, Havardia pallens, and Acacia farnesiana) present different adaptations to conditions of water stress and light saturation [40-42]. 


\section{Conclusions}

According to the results obtained in the present study, the following conclusions are highlighted. 1) The studied community presents intermediate values that are considered common in comparison to other arid and semi-arid vegetation associations of Northeastern Mexico. 2) The abundance curve of the species was well adjusted to the geometric model, and the distribution is associated with adverse environments such as semi-arid. 3) The family with greater importance for its contribution to the community is Fabaceae, while the genus with more species was Acacia. The research generated quantitative information of the plant community of a mesquite which is in a phase of mature ecological succession.

\begin{abstract}
Abbreviations
A: Abundance; Ab: Basal area; AIC: Akaike information criterion; AR: Relative abundance; D: Dominance; dAIC: delta akaike information criterion; DR: Relative dominance; F: Frequency; FR: Relative frequency; IVI: Importance value index; $\mathrm{N}$ : Total number of individuals; Ni: Number of individuals of species; Pij: Proportion of species in each height zone; S: Number of species; S: Surface; Z: Number of height zones
\end{abstract}

\section{Acknowledgements}

We thank the company TERNIUM, Mexico for all the facilities that were granted for the establishment of this research. We are also grateful to Geoprospect S.A. de C.V.

\section{Funding}

RENAC S.A. de C.V. supported for the logistical of the project and field activities.

\section{Availability of data and materials}

Not applicable.

\section{Authors' contributions}

EA-R: Fieldwork, Framing experimental design. VMM-G: Fieldwork, Data analysis and interpretation. JJ-P: Manuscript preparation. EAR-C: Data analysis. AM-O: Identification of specimens. ACC-C: Fieldwork. JJM-C: Fieldwork. Manuscript preparation. All authors read and approved the final manuscript.

\section{Competing interests}

The authors declare that they have no competing interests.

\section{Consent for publication}

Not applicable.

Ethics approval and consent to participate

Not applicable.

\section{Publisher's Note}

Springer Nature remains neutral with regard to jurisdictional claims in published maps and institutional affiliations.

\section{Author details}

${ }^{1}$ Facultad de Ciencias Forestales, Universidad Autónoma de Nuevo León, Carretera Linares-Cd, Victoria Km 145, Apartado Postal 41, 67700 Linares, NL, México. ${ }^{2}$ RENAC, S.A. de C.V. Corregidora 102 Nte, Col. Centro, 67700 Linares, $\mathrm{NL}$, México. ${ }^{3}$ Instituto Nacional de Investigaciones Forestales, Agrícolas y Pecuarias, C.E. Centro Altos de Jalisco, Km. 8, Carretera Libre Tepatitlán-Lagos de Moreno, Tepatitlán de Morenos 47600, Jalisco, México. ${ }^{4}$ Instituto de Ecología Aplicada, Universidad Autónoma de Tamaulipas, División del Golfo 356, 87019 Ciudad Victoria, Tamaulipas, México. ${ }^{5}$ División de Desarrollo Sustentable, Universidad de Quintana Roo, Avenida Andrés Quintana Roo con calle 110 Sur s/n, 77600 Cozumel, Quintana Roo, México.
}

Received: 27 January 2017 Accepted: 19 May 2017

Published online: 14 June 2017

\section{References}

1. Bessega C, Vilardi JC, Saidman BO. Genetic relationships among American species of the genus Prosopis (Mimosoideae, Leguminosae) inferred from ITS sequences: evidence for long-distance dispersal. J Biogeogr. 2006;33:1905-15.

2. Burkhart A, Simpson BB. The genus Prosopis and annotated key to the species of the world. In: Simpson BB, editor. Mesquite, its biology in two desert ecosystems, US/IBP synthesis series No. 4. Stroudsburg, Pa: Dowden, Hutchison and Ross; 1977. p. 201-15.

3. Challenger A, Soberón J. Los ecosistemas terrestres. In: Capital natural de México, vol. I, conocimiento actual de la biodiversidad. México: Comisión Nacional para el Conocimiento y Uso de la Biodiversidad; 2008. p. 87-108.

4. Rzedowski J. Vegetación de México. México: Limusa; 1978.

5. González-Medrano F. Las comunidades vegetales de México. 2nd ed. México: Instituto Nacional de Ecología, Secretaría de Medio Ambiente y Recursos Naturales; 2004.

6. INEGI. Síntesis geográfica de Nuevo León. México: Secretaría de Programación y Presupuesto; 1986.

7. Miranda F, Hernández-X J. Los tipos de vegetación de México y su clasificación. Bol Soc Bot Méx. 1963;28:29-179.

8. Valenzuela-Núñez LM, Trucíos-Caciano R, Ríos-Saucedo JL, Flores Hernández A, González-Barrios JL. Caracterización dasométrica y delimitación de rodales de mezquite (Prosopis sp) en el estado de Coahuila. Rev Chapingo C Forest Amb. 2011;27:87-96

9. Acebes P, Traba J, Peco B, Reus ML, Giannoni SM, Malo JE. Abiotic gradients drive floristic composition and structure of plant communities in the Monte Desert. Rev Chil Hist Nat. 2010;83:395-407.

10. González-Medrano F. La vegetación del nordeste de México. Anales Inst Biol Univ Nac Autón México Bot. 1972;43(1):11-50.

11. Briones $\mathrm{O}$, Villarreal JA. Vegetación y flora de un ecotono entre las provincias del Altiplano y la Planicie Costera del Noreste de México. Acta Bot Mex. 2001;55:39-67.

12. Correa JB. Evaluación y cuantificación de los cambios del uso de suelo mediante imágenes de satélite en los municipios de Linares y Hualahuises. N.L. Monterrey: Dissertation, Facultad de Ciencias Forestales, UANL; 1996.

13. Rojas-Mendoza P. Generalidades sobre la vegetación del estado de Nuevo León y datos acerca de su flora. Mexico: Dissertation, Facultad de Ciencias, Universidad Nacional Autónoma de México; 1965.

14. Villarreal JG. Ganadería diversificada: importancia ecológica, cinegética y económica de los venados cola blanca mexicanos. Monterrey: Monterrey: Secretaría de Agricultura, Ganadería, Desarrollo Rural, Pesca y Alimentación; 2013.

15. APG III. An update of the Angiosperm Phylogeny Group classification for the orders and families of flowering plants: APG III. Bot J Linn Soc. 2009;161:105-121.

16. Tropicos. Missouri Botanical Garden. 2009. http://www.tropicos.org. Accessed 29 Apr 2017

17. Mostacedo B, Fredericksen TS. Manual de métodos básicos de muestreo y análisis en ecología vegetal. Santa Cruz: Editora El País; 2000.

18. Müeller-Dombois $D$, Ellenberg $H$. Aims and methods of vegetation ecology. Nueva York: John Wiley and Sons; 1974.

19. Pretzsch H. Forest dynamics, growth and yield. From measurement to model. Berlín Heidelberg: Springer; 2009.

20. Shannon CE, Weaver W. The mathematical theory of communication Urbana: University of Illinois Press; 1949.

21. Clifford H, Stephenson W. An introduction to numerical classification. New York: Academic; 1975.

22. Doi H, Mori T. The discovery of species-abundance distribution in an ecological community. Oikos. 2012;122:179-82.

23. Green J, Plotkin JB. A statistical theory for sampling species abundances. Ecol Lett. 2007;10:1037-45.

24. Alonso D, McKane AJ. Sampling Hubbell's neutral model of biodiversity. Ecol Lett. 2004:7:901-10.

25. Prado PI, Miranda MD, Chalom A. Sads: Maximum Likelihood Models for Species Abundance Distributions. 2014. http://cran.r-project.org/web/ packages/sads/index.html. Accesed 10 Nov 2016.

26. Magurran AE. Ecological diversity and its measurement. New Jersey: Princeton University Press; 1988. 
27. RStudio. RStudio: Integrated development environment for R. 2014. https:// support.rstudio.com/hc/communities/public/questions/200658933-How-tocite-RStudio. Accessed 10 Nov 2016.

28. Montaño A, García R, Ochoa G, Monroy A. Relación entre la vegetación arbustiva, el mezquite y el suelo de un ecosistema semiárido en México. Terra Lat. 2006;24(2):193-205.

29. Estrada E, Villareal JA, Jurado E. Leguminosas del norte del estado de Nuevo León, México. Acta Bot Mex. 2005;73:1-18.

30. Domínguez-Gómez TG, Ramírez-Lozano RG, González-Rodríguez H, CantúSilva I, Gómez-Meza MV, Alvarado MS. Mineral content in four browse species from Northeastern Mexico. Pakistan J Bot. 2014;46(4):1421-9.

31. Mora-Donjuan CA, Alanís-Rodríguez E, Jiménez-Pérez J, González-Tagle MA, Yerena-Yamallel Jl, Cuellar-Rodríguez LG. Estructura, composición florística y diversidad del matorral espinoso tamaulipeco, México. Ecol Apl. 2013;12(1):29-34.

32. Mora-Donjuan CA, Rubio-Camacho EA, Alanís-Rodríguez E, Jiménez-Pérez J, González-Tagle MA, Mata-Balderas JM, Mora-Olivo A. Composición y diversidad vegetal de un área de matorral desértico micrófilo con historial pecuario en el Noreste de México. Polibotánica. 2014;38:53-66.

33. Pretzsch H. Structural diversity as a result of silvicultural operations. Lesnictvi Forest. 1998;44(10):429-39.

34. Alanís-Rodríguez E, Jiménez-Pérez J, Pando-Moreno M, Aguirre-Calderón $\mathrm{OA}$, Treviño-Garza EJ, Canizales-Velázquez PA. Caracterización de la diversidad arbórea en áreas restauradas post-incendio en el Parque Ecológico Chipinque, México. Acta Biol Colomb. 2010;15(2):309-24.

35. Jiménez-Pérez J, Alanís-Rodríguez E, Aguirre-Calderón O, Pando-Moreno M, González-Tagle M. Análisis sobre el efecto del uso del suelo en la diversidad estructural del matorral espinoso tamaulipeco. Madera Bosq. 2009;15(3):5-20.

36. Villavicencio R, Bauche P, Gallegos A, Santiago AL, Huerta FM. Caracterización estructural y diversidad de comunidades arbóreas de La Sierra de Quila. Bol IBUG. 2005;13(1):67-76.

37. Dávila P, Arizmendi M, Valiente-Banuet A, Villaseñor J, Casas A, Lira R. Biological diversity in the Tehuacán-Cuicatlán Valley, Mexico. Biodivers Conserv. 2002:11:421-42.

38. Jiménez-Pérez J, Alanís-Rodríguez E, Ruiz-González JL, González-Tagle MA, Yerena-Yamallel Jl, Alanís-Flores GJ. Diversidad de la regeneración leñosa del matorral espinoso tamaulipeco con historial agrícola en el NE de México. Ciencia UANL. 2012:15(2):66-71.

39. Pequeño-Ledezma MA, Alanís-Rodríguez E, Jiménez-Pérez J, González-Tagle MA, Yerena-Yamallel Jl, Cuellar-Rodríguez LG, Mora-Olivo A. Análisis de la restauración pasiva post-pecuaria en el matorral espinoso tamaulipeco del noreste de México. Ciencia UAT. 2012;4(2):48-53.

40. González H, Cantú I, Gómez MV, Ramírez RG. Plant water relations of thornscrub shrub species, north-eastern Mexico. J Arid Environ. 2003;58(4):483-503.

41. Passera C. Physiology of Prosopis spp. Latin Am J Nat Resourc. 2000;9(2):53-80.

42. Roche A, Bovey RW, Senseman SA. Water stress and triclopyr on clopyralid efficacy in honey mesquite. J Range Manage. 2002;55(3):266-9.

\section{Submit your next manuscript to BioMed Centra and we will help you at every step:}

- We accept pre-submission inquiries

- Our selector tool helps you to find the most relevant journal

- We provide round the clock customer support

- Convenient online submission

- Thorough peer review

- Inclusion in PubMed and all major indexing services

- Maximum visibility for your research

Submit your manuscript at www.biomedcentral.com/submit

) Biomed Central 